\title{
Intracranial Blastomycosis Presenting as an Enhancing Cerebellopontine Mass
}

\author{
Kontrast Tutan Bir Serebellopontin Kitle Olarak Ortaya Çıkan \\ Intrakraniyal Blastomikoz
}

\author{
Erinc AKTURE ${ }^{1}$, Shahriar SALAMAT ${ }^{2}$, Mustafa Kemal BASKAYA ${ }^{1}$ \\ ${ }^{1}$ University of Wisconsin, Department of Neurological Surgery, Madison, Wisconsin, USA \\ ${ }^{2}$ University of Wisconsin, Pathology and Laboratory Medicine, Madison, Wisconsin, USA
}

Correspondence address: Mustafa Kemal BASKAYA / E-mail: m.baskaya@neurosurgery.wisc.edu

\begin{abstract}
Isolated Blastomyces dermatitidis infection of the central nervous system is an uncommonly encountered entity. If left untreated it can be fatal; thus accurate diagnosis in a timely manner is critical. A 37-year-old white male presented with a severe headache. An MRI scan revealed a rightsided enhancing cerebellopontine angle mass with extension into the internal acoustic canal and diffuse basilar enhancement. After thorough assessment of the patient, an open surgical biopsy of the lesion was performed for pathological evaluation. The biopsy demonstrated broadbased budding yeasts. The cerebrospinal fluid antigen enzyme immunoassay (EIA) (MVista ${ }^{\oplus}$ ) for Blastomyces dermatitidis was also positive with a level of 4.28 EIA units.
\end{abstract}

KEYWORDS: Blastomycosis, Meningitis, Cerebellopontine angle

öz

Merkez sinir sisteminin İzole Blastomyces dermatitidis enfeksiyonu sık rastlanmayan bir durumdur. Tedavi edilmezse ölümcül olabilir ve bu nedenle zamanında doğru tanı koymak çok önemlidir. 37 yaşında bir erkek hasta şiddetli başağrısıyla geldi. MRG taraması sağ tarafta kontrast tutan bir serebellopontin açı kitlesi ve internal akustik kanala yayılmayla difüz baziler kontrast tutma gösterdi. Hasta iyice incelendikten sonra patolojik değerlendirme için lezyonun açık cerrahi biyopsisi yapıldı. Biyopsi geniş tabanlı tomurcuklanan mayalar gösterdi. Blastomyces dermatitidis için serebrospinal sıVı antijen enzim immünoassay (EIA) (MVista ${ }^{\oplus}$ ) testi de 4,28 EIA ünitesi düzeyiyle pozitifti.

ANAHTAR SÖZCÜKLER: Blastomikoz, Menenjit, Serebellopontin açı

\section{INTRODUCTION}

Neoplasms such as schwannomas or meningiomas are at the top of the list of the differential diagnosis for solid looking cerebellopontine angle lesions. However, infectious or inflammatory processes may produce similar imaging studies thus complicating the differential diagnosis. Blastomycosis infection may present in many patterns and mimic a variety of disease conditions, and is thus important to be considered as part of differential diagnosis, particularly in endemic areas (8). While determining patient's risk factors is integral to a complete work-up, the risk factors for blastomycosis are still less well understood and the infection may develop in patients lacking risk factors (3). Furthermore, a team-based approach to the diagnosis and treatment of intracranial lesions with unclear etiology is important in determining the correct diagnosis and therapy within the critical time frame.

\section{CASE PRESENTATION}

A 37-year-old male presented with a severe headache centered bitemporally which was associated with nausea and vomiting. The headache had begun 4 months ago and oc- curred intermittently since then. He also described fatigue and weight loss amounting to eight $\mathrm{kg}(10 \%$ of his total weight) in two months. He had enlarged right anterior cervical lymph nodes treated with amoxicillin in the past. The patient's past medical history was remarkable for anxiety, acid reflux and seasonal allergies. Family history was significant for Crohn's disease. He reported working at a factory that builds and paints military and rescue vehicles. Further questioning revealed that he lives along a river and spends a significant amount of time both fishing in and cleaning the river bed. He denied any smoking and alcohol consumption. Physical examination was remarkable for double vision on left lateral gaze, mild bilateral dysmetria, slightly disturbed tandem gait and hyperreflexia in both lower extremities. Fundoscopic examination revealed papilledema. No skin lesions or lymphadenopathy were detected.

An MRI scan revealed enhancement in the right cerebellopontine angle with extension into the internal auditory canal and diffuse basilar leptomeningeal enhancement (Figure 1A-C). The metastatic work up comprising CT scans of the chest, abdomen and pelvis as well as a PET/CT scan from skull base 
to thigh were not remarkable. The lumbar puncture revealed 415 nucleated cells and 75 red blood cells. The differential showed $87 \%$ lymphocytes with $5 \%$ neutrophils. The patient's protein was 216 with a glucose of 9. Microscopy showed no organisms. The CSF examination for syphilis (RPR, VDRL), Mycobacterium tuberculosis (acid fast staining and culture), fungal stain and culture, Nocardia culture, Cryptococcal antigen, Lyme PCR (Polymerase chain reaction), Lyme Enzymelinked immunosorbent assay (ELISA) (total antibody in CSF), cytomegalovirus (CMV) and Epstein-Barr virus (EBV) qualitative PCR analysis was negative. Serum studies for Lyme ELISA, Lyme IgG Western Blot, Lyme IgM Western Blot, Cryptococcal antigen, Human immunodeficiency virus (HIV) ELISA, VDRL, Brucella serology, serology for Histoplasmosis (complement fixation), serology for Blastomycosis (complement fixation), serology for Toxoplasmosis, and serology for Tularemia were negative. Urine was evaluated for Blastomyces and Histoplasma antigens. Serum serology for Coccidioides immitis (IgM and $\operatorname{lgG}$ ) was also ordered. None of these test yielded a positive result. The patient also had positive anti-nuclear antibody (ANA) with a titer of 1:320 showing speckled pattern.

After discussions with infectious diseases and rheumatology teams, an open surgical biopsy of the lesion was performed. The lesion was approached via right retrosigmoid craniotomy. Abnormal looking, thickened leptomeninges and coating on the flocculus of the cerebellum were excised using microsurgical techniques. Tissue histopathology revealed broad based budding yeasts (Figure 2 A-C) which were suggestive of blastomycosis.

Based on the epidemiological history and histopathological results, treatment with liposomal Amphotericin B was started and continued for 6 weeks. A few days after the initiation of the therapy, the cerebrospinal fluid antigen enzyme immunoassay (EIA) (MVista) for Blastomyces dermatitidis was found to be positive with a level of 4.28 EIA units (EU). Voriconazole therapy was started towards the end of the Amphotericin $B$ regimen and once the level of this drug was therapeutic the patient was switched to single drug therapy with Voriconazole. This treatment lasted one year with regular monitoring of voriconazole serum levels. The response to treatment was followed up with CSF Blastomyces antigen levels until negative levels were achieved. The patient responded very well to the therapy, and his symptoms and papilledema resolved completely.

\section{DISCUSSION}

Endemic areas for Blastomyces dermatitidis in North America include the Mississippi and Ohio River basins as well as regions along the Great Lakes and the St Lawrence River (2). Isolated CNS involvement with Blastomyces dermatitidis is uncommon and may present as meningitis, an intracranial mass lesion, or abscess of the spinal cord or epidural space (2). CNS imaging studies may reveal leptomeningeal enhancement (11). Laboratory diagnosis of blastomycosis meningoencephalitis is difficult to establish because no sensitive or specific serologic test exists, and attempts to isolate the organism in cerebrospinal fluid (CSF) obtained by lumbar puncture generally fail (5). CSF analysis may reveal pleocytosis, with lymphocytic or neutrophilic predominance. The CSF protein level is usually elevated, and CSF glucose level is typically normal or decreased. Isolation of $B$. dermatitidis from CSF culture obtained via lumbar puncture is uncommon. $B$. dermatitidis antigen detection in CSF indicates a positive diagnosis however; cross reactivity especially with other fungal infections, particularly Histoplasma capsulatum, should be kept in mind $(1,2)$. A brain biopsy might be frequently necessary for the diagnosis (5). Biopsy usually has effective yield and the organism can often be seen in simple stains such as hematoxylin and eosin (H\&E) (11). Survival from CNS blastomycosis infection is possible with prompt diagnosis and timely initiation of therapy $(2,5)$.

The mainstay of therapy for CNS blastomycosis is the lipid formulation of Amphotericin B ( $5 \mathrm{mg} / \mathrm{kg}$ per day for 4-6 weeks) followed by an oral azole - typically fluconazole (800 mg per day), itraconazole (200 mg 2 or 3 times per day) or
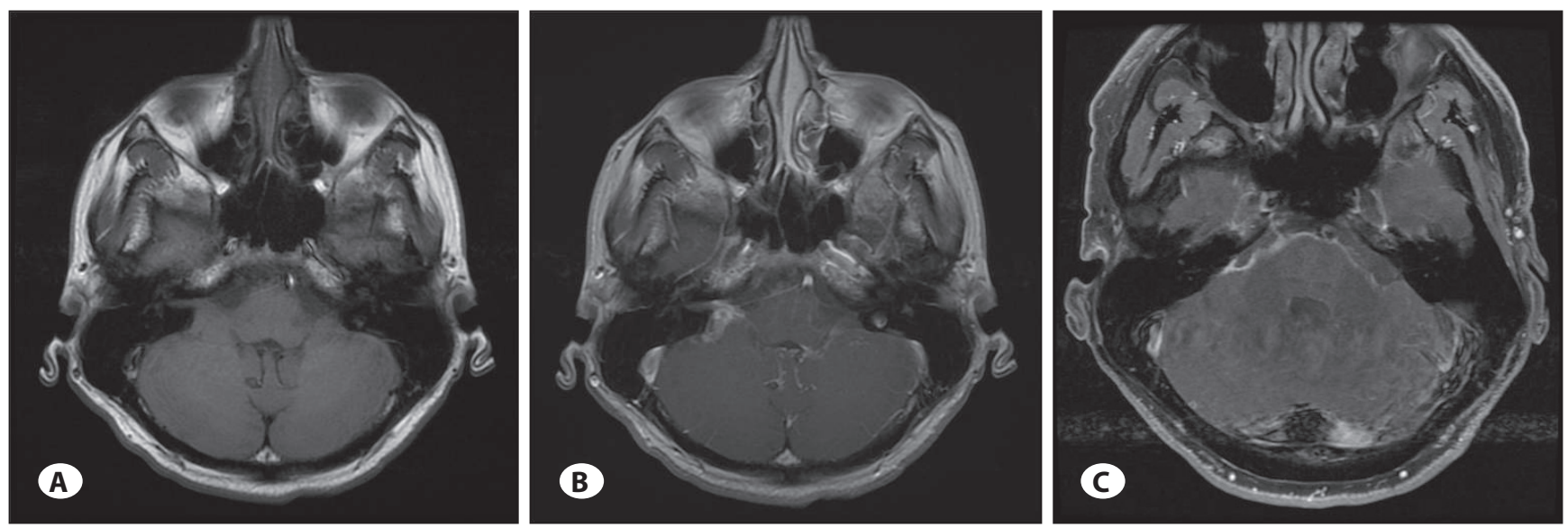

Figure 1: MRI at the time of presentation. (A) T1-weighted axial MRI without contrast. (B) T1-weighted axial MRI with contrast showing right cerebellopontine angle enhancement with extension into the internal auditory canal. (C) T1-weighted axial MRI with contrast showing basilar enhancement. 
voriconazole (200-400 mg twice per day) for at least 12 months (4) (Table I). Itraconazole is the preferred step down azole after Amphotericin B for the treatment of severe nonCNS blastomycosis $(4,8)$. However, it is not considered as the preferred azole in the treatment of CSF blastomycosis due to low CSF levels $(8,9)$. Fluconazole reaches high levels in CSF and there are some case reports on its efficacy in CNS blastomycosis using high doses (800 mg per day) $(2,4,6,10)$. Voriconazole, on the other hand, has excellent CSF penetration and similar antifungal properties as itraconazole (9). Case based evidence suggests that it is being used more frequently than itraconazole and fluconazole in the treatment
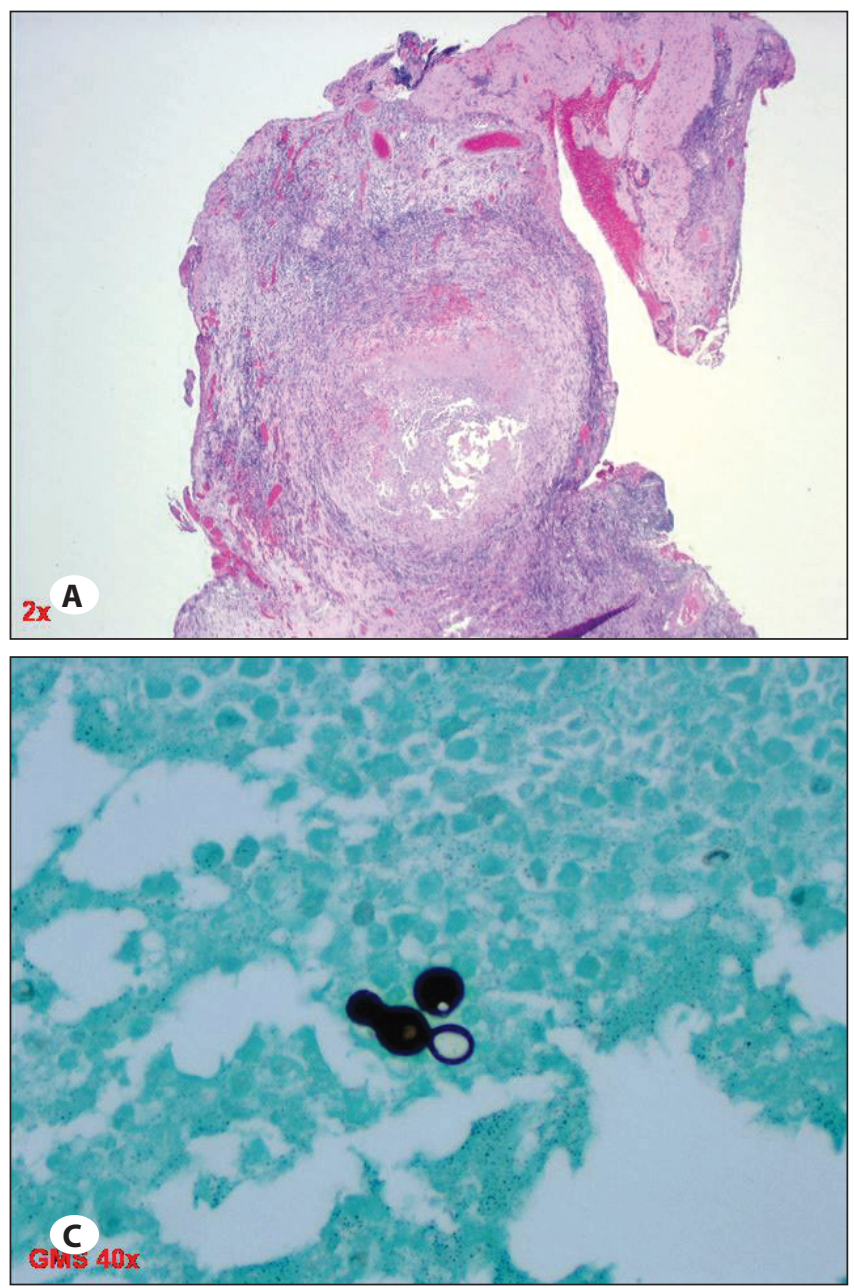

of CNS blastomycosis (2,9). Surgery is also recommended for management of selective cases of osteomyelitis refractory to medical therapy, causing instability of the bone and for lesions of the CNS causing mass effect or for diagnosis if the lesion can be accessed safely $(4,7,11)$.

\section{CONCLUSION}

In this report we demonstrate a case of Blastomyces dermatitidis meningoencephalitis which mimicked a cerebellopontine angle neoplasm with basilar leptomeningeal enhacement. Although we cannot completely rule out disseminated blastomycosis, an extensive work-up revealed no other

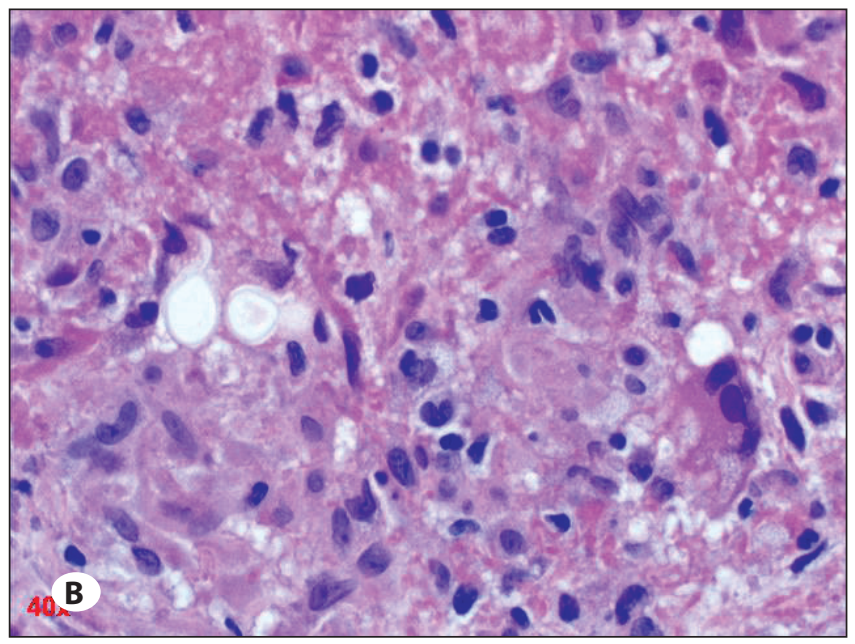

Figure 2: Pathologic examination of the biopsy material. (A) H\&E stain at $2 x$ magnification reveals an intensely inflamed cerebral parenchyma with central necrosis. (B) At 40X magnification the H\&E stained section reveals inflammatory cells, including lymphocytes, epithelioid cells and multinucleated giant cells as well as two yeasts, one of which is budding. (C) GMS stain at 20X magnification demonstrates presence of budding yeast with a broad base.

Table I: Drugs Used in the Treatment of Central Nervous System Blastomycosis

\begin{tabular}{|l|l|l|l|}
\hline $\begin{array}{l}\text { Drug } \\
\begin{array}{l}\text { Amphotericin B (lipid } \\
\text { formulation) }\end{array}\end{array}$ & $\begin{array}{l}\text { Route } \\
\text { Voriconazole }\end{array}$ & IV & $\begin{array}{l}\text { Duration } \\
4-6 \text { weeks (followed by an oral azole for at least one } \\
\text { year) }\end{array}$ \\
$\begin{array}{l}\text { Itraconazole } \\
\text { Fluconazole }\end{array}$ & $\begin{array}{l}200-400 \mathrm{mg} \text { twice per day } 2-3 \text { times per day } \\
800 \mathrm{mg} \text { per day }\end{array}$ & PO & $\begin{array}{l}\text { For at least } 12 \text { months and until resolution of CSF } \\
\text { abnormalities }\end{array}$ \\
\hline
\end{tabular}


organ involvement thus suggesting this is an isolated case of meningoencehalitis. Other than fungal meningoencephalitis, the differential diagnosis of the lesion was very broad and included a cerebellopontine angle neoplasm, systemic lupus erythematosus, tuberculous meningitis, lymphoma and Wegener's granulamatosis. The correct diagnosis was made using a team-based approach involving neurosurgery, neuropathology, infectious diseases and rheumatological diseases specialists. History and physical examination along with an array of diagnostic tests led to the diagnosis. Surgical resection of the lesion not only alleviated pressure symptoms experienced by the patient but also provided the crucial biopsy materials for the histopathological diagnosis.

\section{REFERENCES}

1. Bariola JR, Hage CA, Durkin M, Bensadoun E, Gubbins PO, Wheat LJ, Bradsher RW Jr: Detection of Blastomyces dermatitidis antigen in patients with newly diagnosed blastomycosis. Diagn Microbiol Infect Dis 69:187-191, 2011

2. Bariola JR, Perry P, Pappas PG, Proia L, Shealey W, Wright PW, Sizemore JM, Robinson M, Bradsher RW Jr: Blastomycosis of the central nervous system: A multicenter review of diagnosis and treatment in the modern era. Clin Infect Dis 50:797-804, 2010

3. Cano MV, Ponce-de-Leon GF, Tippen S, Lindsley MD, Warwick M, Hajjeh RA: Blastomycosis in Missouri: Epidemiology and risk factors for endemic disease. Epidemiol Infect 131: 907-914, 2003
4. Chapman SW, Dismukes WE, Proia LA, Bradsher RW, Pappas PG, Threlkeld MG, et al: Clinical practice guidelines for the management of blastomycosis: 2008 update by the Infectious Diseases Society of America. Clin Infect Dis 46:1801-1812, 2008

5. Friedman JA, Wijdicks EF, Fulgham JR, Wright AJ: Meningoencephalitis due to Blastomyces dermatitidis: Case report and literature review. Mayo Clin Proc 75:403-408, 2000

6. Pearson GJ, Chin TW, Fong IW: Case report: Treatment of blastomycosis with fluconazole. Am J Med Sci 303:313-315, 1992

7. Saiz P, Gitelis S, Virkus W, Piasecki P, Bengana C, Templeton A: Blastomycosis of long bones. Clin Orthop Relat Res 255-259, 2004

8. Smith JA, Kauffman CA: Blastomycosis. Proc Am Thorac Soc 7:173-180, 2010

9. Ta M, Flowers SA, Rogers PD: The role of voriconazole in the treatment of central nervous system blastomycosis. Ann Pharmaco Ther 43:1696-1700, 2009

10. Taillan B, Ferrari E, Cosnefroy JY, Gari-Toussaint M, Michiels JF, Paquis P, Lefichoux Y, Dujardin P: Favourable outcome of blastomycosis of the brain stem with fluconazole and flucytosine treatment. Ann Med 24:71-72, 1992

11. Ward BA, Parent AD, Raila F: Indications for the surgical management of central nervous system blastomycosis. Surg Neurol 43:379-388, 1995 